\author{
Катерина Сомова \\ Тетяна Ємець \\ Юлія Калмикова \\ Сергій Калмиков
}

\section{Розвиток гнучкості у тазостегнових суглобах у дітей 5-8 років початкової групи спеціальної фізичної підготовки
3 художньої гімнастики з художньої гімнастики}

Харківська державна академія фізичної культури, Харків, Україна

\begin{abstract}
Мета: оцінити ефективність запропонованої методики тренувань для розвитку гнучкості у тазостегнових суглобах у дітей 5-8 років, що займаються у початковій групі спеціальної фізичної підготовки з художньої гімнастики.

Матеріал і методи: у дослідженні брали участь 16 гімнасток початкової групи спеціальної фізичної підготовки з художньої гімнастики увіці 5-8 років, ОГ - 8 гімнасток, які займались за авторською методикою тренування і КГ - 8 гімнасток, які займались за стандартною методикою тренування. Тренування в обох групах проводилось три рази на тиждень по 1,5 години. Оцінка результатів пасивної та активної гнучкості у тазостегнових суглобах застосовувалась у обох групах на початку обстеження та на 22 день тренування за допомогою тестів «Виконання шпагату з гімнастичної лавки» та «Піднімання ноги догори, лежачи на спині» за Л.А. Карпенко, І.А. Вінер, В.А. Савицьким (2007).

Результати: для розвитку гнучкості у тазостегнових суглобах у дітей основної групи, що займаються у початковій групі спеціальної фізичної підготовки з художньої гімнастики, застосовувалась авторська методика тренування, яка включає вправи на розвиток пасивної та активної гнучкості, мотиваційну частину методики, що сприяє позитивним емоціям дітей, підвищенню уваги та зацікавленості результатом тренування.

Висновки: показники розвитку пасивної та активної гнучкості в основній групі були значно вищими $(p<0,05)$, порівняно з контрольною групою, що свідчить про позитивний вплив застосування авторської методики тренування. Вона сприяє покращенню показників активної та пасивної гнучкості у тазостегнових суглобах за рахунок включення комбінованих вправ, що розвивають усі компоненти рухливості у тазостегнових суглобах, вправ динамічного характеру та силових вправ у поєднанні з примусовим розтягуванням.
\end{abstract}

Ключові слова: активна та пасивна гнучкість, діти, тазостегновий суглоб, художня гімнастика.

\section{Вступ}

Професійний спорт є сферою людської діяльності, для якої характерні підвищені ризики отримати травму. Спостерігаючи динаміку спортивного травматизму, можна визначити, що кількість спортивних травм постійно збільшується і в даний час набуває загрозливих розмірів. У різних країнах світу кількість травм у спорті коливається в межах 10-17\% від усіх ушкоджень. Спортивні травми у США складають 16\% загальної кількості травматичних ушкоджень, у Швеції - 10\%. Ще 40 років тому спортивні травми становили тільки $1,4 \%$ усіх травм. У 1970 році ця цифра збільшилася до 5-7\%. До кінця 80-х - початку 90-х років кількість спортивних травм перевищила $10 \%$, в середині $90-x$ років становила $12-17 \%$, а в період 2001-2010 рр. досягла 17-20\%.

Гімнастика - це своєрідна історично сформована форма фізичної діяльності, яка представляє собою систему спеціально підібраних вправ і методів, яка у поєднанні з іграми, туризмом, плаванням та іншими засобами ефективно впливає на зміцення здоров'я та фізичний розвиток, вдосконалення рухових здібностей людини, а у спортивній діяльності - високим досягненням у багатьох видах спорту, особливо у мистецтві володіння тілом [1].

Етапи спортивної підготовки - це умовний розподіл процесу підготовки згідно з віком та рівнем підготовленості (майстерності), що ґрунтується на закономірностях вікового розвитку рухового аналізатора, рухової системи особистості та її здібностей адекватно вимогам гімнастики.

І етап - початкова спортивна підготовка (з 5-6 років до 8 років). Умови спортивної підготовки визначаються ще на ранніх етапах здібностями гімнаста та тренера долати труднощі та спільним прагненням досягти висот спортивної майстерності у гімнастиці.

У художній гімнастиці найбільш часто травмуються нижні кінцівки (50-65\%), верхні кінцівки (35-50\%), тулуб і хребет (15-20\%). Крім того, до недавнього часу на етапі початкової підготовки починали займатися гімнастикою у 7-9 років, то за сучасними програмами дозволено залучати до занять дітей з 5-6, а іноді - з 4 років [4]. Тому 
на сьогоднішній день існує проблема розробки сучасного підходу до розвитку гнучкості дівчаток 5-8 років, що займаються художньою гімнастикою. Важливо модифікувати існуючі методики тренувань, особливо у початкових групах спеціальної фізичної підготовки для збереження здоров'я дітей, формування основ здорового способу життя та сприяння популяризації занять спортом серед молоді [7; 10].

Мета дослідження: оцінити ефективність запропонованої методики тренувань для розвитку гнучкості у тазостегнових суглобах у дітей 5-8 років, що займаються у початковій групі спеціальної фізичної підготовки 3 художньої гімнастики.

\section{Матеріал і методи дослідження}

Дослідження проводилося на базі ХДЮсШ № $1 \mathrm{~m}$. Харкова. У обстеженні брали участь 16 гімнасток початкової групи спеціальної фізичної підготовки з художньої гімнастики у віці 5-8 років, вони були довільно розподілені на дві групи: основну групу (ОГ) - 8 гімнасток, які займались за авторською методикою тренування, і контрольну групу (КГ) - 8 гімнасток, які займались за стандартною методикою тренування. Тренування в обох групах проводилися три рази на тиждень по 1,5 години.

Первинне та повторне обстеження в ОГ та КГ гімнасток проводилось на 1 та на 22 день тренування.

Для визначення пасивної та активної гнучкості у тазостегнових суглобах у обох груп ми застосовували тест «Виконання шпагату з гімнастичної лавки», та «Підніман- ня ноги догори, лежачи на спині» за Л.А. Карпенко, І.А. Вінер, В.А. Савицьким (2007) [5].

Тест 1. «Виконання шпагату з гімнастичної лавки» (оцінка пасивної гнучкості у тазостегнових суглобах). Проведення тесту: 1 - з правої ноги, 2 - з лівої ноги, 3 - поперечний шпагат. Оцінювання: максимальна оцінка тесту - 5 балів. Бали виставлялися відповідно до таблиці 1.

Тест 2. «Піднімання ноги догори, лежачи на спині» (оцінка активної гнучкості у тазостегнових суглобах). Проведення тесту: вихідне положення - лежачи на спині підняти праву (ліву) ногу догори, не відриваючи таз від підлоги. Тримати 3 секунди. Оцінювання: вимірюється відстань від тильної поверхні стопи до підлоги (см), максимальна оцінка тесту - 5 балів. Бали виставлялися відповідно до таблиці 2.

\section{Результати дослідження}

Гнучкість - здатність виконувати рухи з більшою амплітудою. Розрізняють: активну гнучкість, що досягається напруженням власних м'язів, та пасивну, що здійснюється за рахунок зовнішньої сили (ваги тіла, зусилля партнера, використання тренажерів та ін.).

Складна рухова діяльність не виявляє окремих фізичних якостей в їх чистому, ізольованому вигляді. Майже повсюди діє сполучення різних фізичних якостей. На етапі початкової підготовки для виконання змагальних композицій необхідно освоювати елементи, що вимагають прояву різних видів гнучкості: пасивної та активної [2; 9].

Таблиця 1

Оцінка пасивної гнучкості у тазостегнових суглобах за результатами тесту «Виконання шпагату з гімнастичної лавки»

\begin{tabular}{|c|c|c|}
\hline Критерії оцінювання & Бали & $\begin{array}{c}\text { Рівень } \\
\text { виконання }\end{array}$ \\
\hline Виконання на підлозі, відстань до підлоги 15 см і більше & 1 & \multirow[b]{2}{*}{ низький } \\
\hline $\begin{array}{l}\text { Виконання на підлозі, відстань до підлоги від } 15 \text { см і до торкання } \\
\text { підлоги }\end{array}$ & 2 & \\
\hline Ідеальне виконання на підлозі & 3 & середній \\
\hline $\begin{array}{l}\text { Щільне торкання підлоги стегном, середина стопи знаходиться } \\
\text { на лавці }\end{array}$ & 4 & \multirow[t]{2}{*}{ високий } \\
\hline Щільне торкання підлоги стегном, п’ятка знаходиться на лавці & 5 & \\
\hline
\end{tabular}

Таблиця 2

Оцінка активної гнучкості у тазостегнових суглобах за результатами тесту «Піднімання ноги догори, лежачи на спині»

\begin{tabular}{|c|c|c|}
\hline Критерії оцінювання (см) & Бали & \multirow{2}{*}{ Рівень виконання } \\
\cline { 1 - 2 } 40 і більше & 1 & \multirow{2}{*}{ низький } \\
\hline 35 & 2 & \multirow{2}{*}{ середній } \\
\hline 30 & 3 & високий \\
\hline 25 & 5 & в \\
\hline від 20 і менше & 4 & \\
\hline
\end{tabular}




\section{Результати первинного дослідження пасивної та активної гнучкості в основній та контрольній групах}

\begin{tabular}{|c|c|c|c|c|c|}
\hline \multirow{2}{*}{\multicolumn{2}{|c|}{ Тести }} & \multicolumn{2}{|c|}{ Групи обстежених } & \multirow{3}{*}{$\begin{array}{c}\mathrm{t} \\
0,07 \\
\end{array}$} & \multirow{3}{*}{$\begin{array}{c}\mathrm{p} \\
>0,05\end{array}$} \\
\hline & & \multirow{2}{*}{$\begin{array}{c}\mathrm{O} \Gamma, \mathrm{n}=8 \\
2,02 \pm 0,68\end{array}$} & \multirow{2}{*}{$\frac{\mathrm{K} \Gamma, \mathrm{n}=8}{2,07 \pm 0,37}$} & & \\
\hline \multirow{3}{*}{$\begin{array}{l}\text { Тест 1. Оцінка пасивної } \\
\text { гнучкості у } \\
\text { тазостегнових суглобах }\end{array}$} & 3 правої ноги & & & & \\
\hline & з лівої ноги & $1,83 \pm 0,51$ & $1,79 \pm 0,69$ & 0,05 & $>0,05$ \\
\hline & $\begin{array}{l}\text { поперечний } \\
\text { шпагат }\end{array}$ & $1,89 \pm 0,91$ & $1,90 \pm 1,11$ & 0,09 & $>0,05$ \\
\hline \multicolumn{2}{|c|}{$\begin{array}{l}\text { Тест 2. Оцінка активної гнучкості у } \\
\text { тазостегнових суглобах }\end{array}$} & $1,85 \pm 0,38$ & $1,89 \pm 0,27$ & 0,86 & $>0,05$ \\
\hline
\end{tabular}

На думку М.А. Годик, пасивна гнучкість визначається за тією найбільшою амплітудою, яка може бути досягнута за рахунок зовнішньої сили. Величина її повинна бути однаковою для всіх вимірювань, тільки в цьому випадку можна отримати об'єктивну оцінку пасивної гнучкості [3]. Величину пасивної гнучкості визначають в момент, коли дія зовнішньої сили викликає больове відчуття. Отже, показники пасивної гнучкості гетерогенні і залежать не стільки від стану м'язового і суглобового апаратів, а й від здатності спортсмена якийсь час терпіти неприємні відчуття. Тому важливо так мотивувати його, щоб він не припинив тест при появі перших ознак болю.

Розвитку активної та пасивної гнучкості у художній гімнастиці приділяється багато уваги. Ю.В. Менхен, Л.В. Волков, В.М. Платонов, К.П. Сахновський вважають, що навантаження при виконанні вправ з пасивним розтягуванням не однакове, в статичних положеннях воно більше, ніж у махових. Тому необхідне різне дозування вправ [6].

Загальна втома при виконанні вправ зменшує амплітуду рухів, знижує ефективність вправ. Якщо вправи виконуються з обтяженням, вага його не повинна значно знижувати швидкість махів або пружних рухів (обтяження не повинні перевищувати 2-3\% від ваги тіла спортсмена). Умови виконання рухів значно полегшуються за рахунок використання опори.

Співвідношення роботи, спрямованої на розвиток активної і пасивної гнучкості в межах річного циклу змінюється. На ранніх етапах тренувального року переважають засоби розвитку пасивної гнучкості, що є основою для подальшої роботи над розвитком активної гнучкості. В подальшому обсяг вправ, які сприяють розвитку активної гнучкості, збільшується.

Застосування вправ для другого етапу розвитку гнучкості базується на тих самих методах, що і розвиток сили. Основним принципом при цьому є принцип повторних зусиль 3 максимальним напруженням у всіх режимах роботи: повільному, швидкому і статичному. Такі вправи несуть в собі значно більше навантаження, ніж пасивні вправи. Тому знижується кількість повторень і кількість підходів, збільшується тривалість відпочинку між підходами і зміст відпочинку змінюється.

Використання примусового розтягування має безсумнівну перевагу перед іншими методами розвитку пасивної рухливості в суглобах, однак, у розвитку активної форми гнучкості в усіх напрямках значно ефективніше активний і змішаний режими тренування [8]. У той же час примусове розтягування, яке забезпечує найбільшу (анатомічно можливу) рухливість у суглобах, несе в собі і больові відчуття, і підвищення ризику травмування.

В.М. Платонов, К.П. Сахновський вважають, що щоб зберегти рухливість в суглобах, потрібно кожний день давати їм «роботу». Комплекс вправ, які розвивають активну гнучкість, а також активно-статичні силові вправи, які потребують максимального прояву гнучкості, застосовуються не більше 3-х разів на тиждень; вправи, які сприяють розвитку пасивної гнучкості, можна виконувати щодня [6].

За результатами первинного дослідження у 62,5\% гімнасток визначався низький рівень пасивної гнучкості, у $37,5 \%$ гімнасток - середній рівень пасивної гнучкості, низький рівень активної гнучкості - 100\% гімнасток (табл. 3).

Подібні результати пояснюються недостатнім розвитком еластичності зв язок та м'язів, щоб підтримувати себе в статичному положенні впродовж певного часу, а також недостатнім розвитком сили м'язів, щоб підтримувати максимально можливу амплітуду руху у гімнасток. Психоемоційна сфера дівчат у віці 5-8 років також ще не здатна витримати навантаження - юним гімнасткам досить важко розслабити м'язи, щоб збільшити амплітуду руху.

3 метою розвитку гнучкості тазостегнових суглобів дітей 5-8 років, що займаються у початковій групі спеціальної фізичної підготовки з художньої гімнастики, нами була запропонована авторська методика тренування, яка включала вправи на розвиток пасивної та активної гнучкості, мотиваційну частину методики, що буде сприяти позитивним емоціям дітей, підвищенню уваги і зацікавленості результатом тренування.

\section{Вправи на розвиток пасивної гнучкості}

1. Вихідне положення (в.п.): сидячи, ноги нарізно з нахилом, руки вгору. На видиху опустити тулуб до підлоги. Повернутись у вихідне положення.

2. В.п.: лежачи лівим боком. Мах правою ногою та лівою рукою здійснювати одночасно перед собою: в сторону - догори до обхвату гомілки рукою. Утримувати положення 20 с. Повторити на правому боці.

3. Шпагати правою, лівою, повздовжній шпагат.

4. Шпагати зі збільшенням кута підйому ноги від підлоги - використання першої, другої рейки гімнастич- 
ної стінки (залежно від вихідного рівня гнучкості) - утримання положення: руки догори у висі впродовж 2 хв. (починати з 1 хвилини, поступово збільшувати час виконання вправи залежно від розвитку якості).

\section{Вправи для розвитку активної гнучкості}

1. В.п.: сидячи, ноги нарізно, руки у другій позиції. Поворот тулуба вправо з відведенням правої руки вбік, лівої руки вперед. Лівим коліном торкнутись підлоги. Повернутись у в.п. Повторити вправу в інший бік.

2. В.п.: сидячи, ноги нарізно з нахилом, руки вгору. Прийняти положення. Упор присівши - руки поставити на підлогу на відстані 15-20 см від носків, вагу тіла рівномірно перенести на руки та ноги, голову тримати прямо. Прийняти положення: упор стоячи, зігнувшись з положення упор присівши максимально нахилити тулуб вперед та наблизити до стегон, ноги прямі, руки долонями поставити на підлогу на рівні носків ніг, дивитись на носки. Повернутися у вихідне положення.

3. Виконувати вправу в парі: В.п.: положення навпроти партнера, сидячи, ноги нарізно, почергово нахиляючись назад - нахиляти партнера вперед пружинними рухами.

4. В.п.: стоячи біля гімнастичної стінки, триматися за нею рукою. Мах ногою вперед, назад, в сторону-догори з максимальною амплітудою. При виконанні рухів ступню повертати назовні, тіло і голову тримати прямо.

5. В.п.: стоячи біля гімнастичної стінки, триматися за нею рукою. Рух ноги вперед, назад, в сторону-догори з використанням обтяжень.

6. В.п.: лежачи на спині, руки вгору, підйом тулуба, положення сидячи, ноги нарізно з нахилом, повернутись у в.п. Дихання довільне.

Заняття, спрямовані на збільшення рухливості в суглобах, повинні проводитись кожний день. Для підтримки гнучкості на вже досягнутому рівні можна скоротити кількість занять до 2-3 на тиждень. При цьому можливе скорочення об'ємів виконання вправ на розтягування у кожному тренувальному занятті. Усі пасивні рухи доціль- но виконувати в 3-4 підходи, кожне з 10-40 повтореннями. Статичні положення утримуються по 6-10 с у 3-4 підходах. Розслаблені виси виконуються по 30 с в 2-3 підходи. Середній темп при виконанні активних вправ складає одне повторення за $1 \mathrm{c}$, при виконанні пасивних вправ - одне повторення за 1-2 с, утримання статичних положень - протягом 20-30 с. Тривалість заняття - від 20-30 до 45-60 хв.

3 метою підвищення інтересу до тренувань у юних гімнасток та набуття перших змагальних навичок доцільно використання додаткових засобів і методів тренування.

\section{Мотиваційна частина методики}

- Оцінка якості тренування. Результат кожного тренування гімнастки оцінюється тренером не системою оцінок, а видачею «наліпок», які відповідають ступеню активності на занятті: тому, хто проявив себе якнайкраще на тренуванні тренер дає можливість обрати наліпку першим, самостійно. Тим, хто проявив себе недостатньо слухняним та старанним - обирає наліпку тренер. Важливо врахувати, що в обраній групі гімнастки мають різній рівень розвитку гнучкості, на етапі початкової підготовки технічні навички ще слабо розвинуті, тому перш за все оцінюється слухняність, старання гімнастки, незалежно від початкового рівня гнучкості. У групі гімнасток 7-8 років замість наліпок можна включити систему оцінок (1-5), включити до оцінювання перші технічні навички.

- Обирання для демонстрації вправ найстараннішої спортсменки. На показ кожної наступної вправи тренер обирає нову гімнастку, що дуже старанно виконує вправи, прикладає максимум зусиль. Дає розвиток перших змагальних навичок, бажання у гімнасток якісно виконувати вправи.

- Розучування танцю групою. Щоб підтримувати інтерес гімнасток до кінця тренування (в залежності від рівня втоми) тренер обирає танцювальні рухи та музику, що будуть виконувати діти в заключній частині заняття.

у результаті тритижневого тренування гнучкості показники активної та пасивної гнучкості спортсменок

Таблиця 4

Результати первинного та повторного дослідження пасивної та активної гнучкості в основній та контрольній групах

\begin{tabular}{|c|c|c|c|c|c|}
\hline \multirow{2}{*}{\multicolumn{2}{|c|}{ Тести }} & \multicolumn{2}{|c|}{ Періоди дослідження } & \multirow[b]{2}{*}{$\mathrm{t}$} & \multirow[b]{2}{*}{$\mathrm{p}$} \\
\hline & & $\begin{array}{c}\text { Первинне } \\
\text { дослідження }\end{array}$ & $\begin{array}{c}\text { Повторне } \\
\text { дослідження }\end{array}$ & & \\
\hline \multicolumn{6}{|c|}{ Основна група, $(\mathrm{n}=8)$} \\
\hline \multirow{3}{*}{ Тест 1} & З правої ноги & $2,02 \pm 0,68$ & $4,2 \pm 0,62$ & 2,37 & $<0,05$ \\
\hline & з лівої ноги & $1,83 \pm 0,51$ & $4,0 \pm 0,65$ & 2,63 & $<0,05$ \\
\hline & поперечний шпагат & $1,89 \pm 0,91$ & $4,1 \pm 0,90$ & 1,72 & $>0,05$ \\
\hline Тест 2 & Оцінка активної гнучкості & $1,85 \pm 0,38$ & $3,7 \pm 0,50$ & 2,95 & $<0,05$ \\
\hline \multicolumn{6}{|c|}{ Контрольна група, (n=8) } \\
\hline \multirow{3}{*}{ Тест 1} & З правої ноги & $2,07 \pm 0,37$ & $3,1 \pm 0,66$ & 1,36 & $>0,05$ \\
\hline & з лівої ноги & $1,79 \pm 0,69$ & $2,9 \pm 1,12$ & 0,84 & $>0,05$ \\
\hline & поперечний шпагат & $1,90 \pm 1,11$ & $3,0 \pm 1,0$ & 0,74 & $>0,05$ \\
\hline Тест 2 & Оцінка активної гнучкості & $1,89 \pm 0,27$ & $3,1 \pm 0,82$ & 1,55 & $>0,05$ \\
\hline
\end{tabular}




\section{Таблиця 5 \\ Результати повторного дослідження пасивної та активної гнучкості в основній та контрольній групах}

\begin{tabular}{|c|c|c|c|c|c|}
\hline \multirow{2}{*}{\multicolumn{2}{|c|}{ Тести }} & \multicolumn{2}{|c|}{ Групи обстежених } & \multirow{2}{*}{$\mathrm{t}$} & \multirow{2}{*}{$\mathrm{p}$} \\
\hline & & $\mathrm{O} \Gamma, \mathrm{n}=8$ & $\mathrm{~K} \Gamma, \mathrm{n}=8$ & & \\
\hline \multirow{3}{*}{$\begin{array}{l}\text { Тест 1. Оцінка пасивної } \\
\text { гнучкості у } \\
\text { тазостегнових суглобах }\end{array}$} & з правої ноги & $4,2 \pm 0,62$ & $3,1 \pm 0,66$ & 1,19 & $>0,05$ \\
\hline & з лівої ноги & $4,0 \pm 0,65$ & $2,9 \pm 1,10$ & 0,86 & $>0,05$ \\
\hline & $\begin{array}{l}\text { поперечний } \\
\text { шпагат }\end{array}$ & $4,1 \pm 0,90$ & $3,0 \pm 1,0$ & 0,82 & $>0,05$ \\
\hline \multicolumn{2}{|c|}{$\begin{array}{l}\text { Тест 2. Оцінка активної гнучкості у } \\
\text { тазостегнових суглобах }\end{array}$} & $3,7 \pm 0,50$ & $3,1 \pm 0,82$ & 0,63 & $>0,05$ \\
\hline
\end{tabular}

обох груп значно покращилися, можна зазначити, що деякі гімнастки досягли найвищого рівня гнучкості, за результатами тестування, за рахунок набуття вміння досягати найбільшої рухливості та еластичності зв`язок внаслідок розслаблення м'язів стегна. Рівень активної гнучкості підвищився тільки до середнього рівня майже у всіх гімнастів, що пов'язано з недостатнім розвитком силових якостей. Так, при повторному дослідженні спостерігалось статистично значуще поліпшення показників активної та пасивної гнучкості в основній групі, у порівнянні з первинним. У контрольній групі також ми спостерігали покращення досліджуваних показників при повторному дослідженні, у порівнянні з результатами первинного дослідження (табл. 4).

При порівнянні повторних результатів тестування в ОГ та КГ ми спостерігали статистично значущі кращі результати дослідження активної та пасивної гнучкості у тазостегнових суглобах в основній групі, у порівнянні з групою контролю, що свідчить про ефективніший вплив запропонованої методики тренування на розвиток активної та пасивної гнучкості $(p<0,05)$ (табл. 5).

Для розвитку активної гнучкості є доцільним включення до тренувальної методики комбінованих вправ, що розвивають усі компоненти рухливості у тазостегнових суглобах, а також вправ динамічного характеру та силових вправ.

Для досягнення високого рівня розвитку якості пасивні вправи мало ефективні. Значно більший ефект досягається, коли в тренуванні використовують активний режим з обтяженням, а також змішаний режим роботи м'язів. Використання примусового розтягування має безсумнівну перевагу перед іншими методами розвитку пасивної рухливості в суглобах, однак, у розвитку активної форми гнучкості в усіх напрямках значно ефективнішим $€$ активний і змішаний режими тренування. У той же час помітне покращання відбувається у випадку, коли разом з активним режимом використовують примусове розтягування, яке забезпечує найбільшу (анатомічно можливу) рухли- вість у тазостегнових суглобах за рахунок розслаблення м'язів та підвищення еластичності зв`язок [8].

\section{Висновки / Дискусія}

Аналіз літературних джерел виявив, що для досягнення високого рівня розвитку гнучкості пасивні вправи малоефективні. Значно більший ефект досягається, коли в тренуванні використовують активний режим з обтяженням, а також змішаний режим роботи м'язів.

Для розвитку активної гнучкості є доцільним включення до тренувальної методики комбінованих вправ, що розвивають усі компоненти рухливості у тазостегнових суглобах, вправ динамічного характеру та силових вправ. У тренуванні є доцільним використання активного режиму з обтяженням, а також змішаного режиму роботи м'язів у поєднанні з примусовим розтягуванням, яке забезпечує найбільшу (анатомічно можливу) рухливість у тазостегнових суглобах. Комплекс вправ, які розвивають активну гнучкість, а також активно-статичні силові вправи, які потребують максимального прояву гнучкості, застосовуються не більше 3-х разів на тиждень; вправи, які сприяють розвитку пасивної гнучкості можна виконувати щодня.

Мотиваційна частина методики стимулює гімнасток отримати позитивний відгук від групи, тим самим викликає бажання отримати кращий результат і дозволяє підвищити ефективність тренувань.

Впровадження авторської методики тренування сприяло покращенню показників активної та пасивної гнучкості у тазостегнових суглобах, за рахунок включення комбінованих вправ, що розвивають усі компоненти рухливості у тазостегнових суглобах, а також вправ динамічного характеру та силових вправ у поєднанні з примусовим розтягуванням.

Перспективи подальших досліджень. Перспективним $€$ розробка підготовчих вправ для гімнасток 3 метою профілактики травматизму при підвищенні гнучкості тазостегнового суглобу.

Конфлікт інтересів. Автори заявляють, що відсутній конфлікт інтересів, який може сприйматись таким, що може завдати шкоди неупередженості статті.

Джерела фінансування. Ця стаття не отримала фінансової підтримки від державної, громадської або комерційної організації. 


\section{Список посилань}

1. Айунц Л. Р. (2008), Гімнастика. Житомир, 62 с

2. Власова О. П. (2011), Развитие гибкости при обучении элементам без предмета на этапе начальной подготовки в художественной гимнастике: автореф. дис. канд. пед. наук. Омск, 23 с.

3. Годик Н. А. (1988), Спортивная метрология. Москва, 191 с.

4. Гуменюк С. В. (2020), Спортивний травматизм та його профілактика. Тернопіль, С. 66-69.

5. Карпенко Л. А., Винер И. А., Сивицкий В. А. (2007), Методика оценки и развития физических способностей у занимающихся художественной гимнастикой. Москва, С. 19-20.

6. Менхин Ю. В., Волков А. В. (1980), Начала гимнастики. Киев, С. 58-62.

7. Платонов В. Н., Сахновский К. П. (1985), Подготовка юного спортсмена. Киев, С 173-190.

8. Пугач Н. В. (2017), Теорія і методика розвитку фізичних якостей в хореографії. Львів, С. 3-13.

9. Білокопитова Ж. А., Нестерова Т. В., Дерюгіна А. М., Безсонова В. А. (1999), Художня гімнастика: навчальна програма для ДЮСШ, СДЮШОР, ШВСМ, РНМК. Державний комітет України з фізичної культури і спорту. Київ, 48 с.

10. Развитие гибкости на этапе начального обучения в художественной гимнастике (2015). URL: https://cyberleninka.ru/ article/n/razvitie-gibkosti-na-etape-nachalnogo-obucheniya-v-hudozhestvennoy-gimnastike

11. Evila-Carvalho L., Klentrou P., Palomero M. d. L., Lebre E. (2014), «Body composition profile of elite group rhythmic gymnastics», Science of Gymnastics Journal, Vol. 4, No. 1, pp. 21-32.

12. Carvalho L. A., Klentrou P., Lebre E. (2012), "Handling, throws, catches and collaborations in elite group rhythmic gymnastics», Science of Gymnastics Journal, Vol. 4, No. 3, pp. 37-47

13. Fortios M., Miltiadis P., Eirini A., Andromahi S. (2012), «Dynamic Balance in Girls Practicing Recreational Rhythmic Gymnastics and Greek Traditional Dances», Science of Gymnastics Journal, Vol. 5, No. 1, pp. 61-70.

14. Gallahue D. L., Ozmun J. C. (2006), Understanding Motor Development (Infants, Children, Adolescents, and Adults). New York: McGraw-Hill, 125 p.

15. Kosmidau E., Giannitspoulou E., Proios M. (2015), «Perceived locus of control in rhythmic gymnastics by coaches and judges», Sport Science Review, Vol. XXIV, No. 1-2, pp. 89-102.

16. Wang Z. (2016), "Proprioception influence on rhythmic gymnastics sport skill formation based on physiology theory», Journal of Chemical and Pharmaceutical Research, Vol. 1, pp. 57-61.

Стаття надійшла до редакції: 04.08.2021 р.

Опубліковано: 31.08.2021 p.

Аннотация. Екатерина Сомова, Татьяна Емец, Юлия Калмыкова, Сергей Калмыков. Развитие гибкости в тазобедренных суставах у детей 5-8 лет начальной группы специальной физической подготовки по художественной гимнастике. Цель: оценить эффективность предложенной методики тренировки для развития гибкости в тазобедренных суставах у детей 5-8 лет, занимающихся в начальной группе специальной физической подготовки по художественной гимнастике. Материал и методы: в исследовании принимали участие 16 гимнасток начальной группы специальной физической подготовки по художественной гимнастике в возрасте 5-8 лет, ОГ - 8 гимнасток, которые занимались по авторской методике тренировки? и КГ - 8 гимнасток, которые занимались по стандартной методике тренировки. Тренировка в обеих группах проводилfсь три раза в неделю по 1,5 часа. Оценка результатов пассивной и активной гибкости в тазобедренных суставах применялась в обеих группах в начале обследования и на 22 день тренировки, с помощью тестов «Выполнение шпагата с гимнастической скамейки» и «Подъем ноги вверх, лежа на спине» по Л. Карпенко, И.А. Винер, В.А. Савицким (2007). Результаты: для развития гибкости в тазобедренных суставах у детей основной группы, занимающихся в начальной группе специальной физической подготовки по художественной гимнастике, применялась авторская методика тренировки, которая включает упражнения на развитие пассивной и активной гибкости, мотивационную часть методики, способствующую положительным эмоциям детей, повышению внимания и заинтересованности результатом тренировки. Выводы: показатели развития пассивной и активной гибкости в основной группе были значительно выше ( $p<0,05)$, по сравнению с контрольной группой, что свидетельствует о положительном влиянии применения авторской методики тренировки. Она способствует улучшению показателей активной и пассивной гибкости в тазобедренных суставах за счет включения комбинированных упражнений, развивающих все компоненть подвижности в тазобедренных суставах, упражнений динамического характера и силовых упражнений в сочетании с принудительной растяжкой.

Ключевые слова: активная и пассивная гибкость, дети, тазобедренный сустав, художественная гимнастика.

Abstract. Katerina Somova, Tetiana Yemets, Yuliya Kalmykova, Serhii Kalmykov. Development of flexibility in the hip joints in children 5-8 years of the initial group of special physical training in rhythmic gymnastics. Purpose: to evaluate the effectiveness of the proposed training technique for the development of flexibility in the hip joints in children 5-8 years, engaged in the initial group of special physical training in rhythmic gymnastics. Material and methods: 16 gymnasts of the initial group of special physical training in rhythmic gymnastics at the age of 5-8 years, OG - 8 gymnasts who were engaged in the author's training method and KG - 8 gymnasts who were engaged in the standard training method took part in the research. Training in both groups was conducted three times a week for 1.5 hours. Assessment of the results of passive and active flexibility in the hip joints was used in both groups at the beginning of the examination and on day 22 of training, using tests «Performing twine from a gymnastic bench» and «Lifting the leg up lying on your back» by L.A. Karpenko, I.A. Wiener, V.A. Savitsky (2007). Results: for the development of flexibility in the hip joints in children of the main group engaged in the initial group of special physical training in rhythmic gymnastics, the author's training technique was used, which includes exercises to develop passive and active flexibility, motivational part of the technique that promotes positive emotions increasing attention and interest in the result of training. Conclusions: indicators of development of passive and active flexibility in the main group were significantly higher $(p<0.05)$, compared with the control group, which indicates a positive effect of the use of the author's training methods. It helps to improve the indicators of active and passive flexibility in the hip joints by including combined exercises that develop all the components of mobility in the hip joints, dynamic exercises and strength exercises in combination with forced stretching.

Keywords: active and passive flexibility, children, hip joint, rhythmic gymnastics. 


\section{References}

1. Aiunts, L. R. (2008), Gymnastics. Zhytomyr, 62 p. (in Ukr.).

2. Vlasova, O. P. (2011), The development of flexibility in teaching elements without a subject at the stage of initial training in rhythmic gymnastics: author. dis. Cand. ped. sciences. Omsk, 23 p. (in Russ.).

3. Godik, N. A. (1988), Sports metrology. Moscow, 191 p. (in Russ.).

4. Gumenyuk, S. V. (2020), Sports injury and its prevention. Ternopil, pp. 66-69. (in Ukr.).

5. Karpenko, L. A., Viner, I. A., \& Sivitskiy, V. A. (2007), Methods for assessing and developing physical abilities among those who go in for rhythmic gymnastics. Moscow, pp. 19-20. (in Russ.).

6. Menkhin, Yu. V., \& Volkov, A. V. (1980), Beginning of gymnastics. Kiev, pp. 58-62. (in Russ.).

7. Platonov, V. N., \& Sakhnovskiy, K. P. (1985), Training of a young athlete. Kiev, pp. 173-190. (in Russ.).

8. Puhach, N. V. (2017), Theory and methods of development of physical qualities in choreography. Lviv, pp. 3-13. (in Ukr.).

9. Bilokopytova, Zh. A., Nesterova, T. V., Deriuhina, A. M., \& Bezsonova, V. A. (1999), Rhythmic gymnastics: Curriculum for CYSS, SDYUSHOR, SHVSM, RNMK, State Committee of Ukraine for Physical Culture and Sports. Kyiv, 48 p. (in Ukr.).

10. Development of flexibility at the initial stage of training in rhythmic gymnastics (2015), URL: https://cyberleninka.ru/article/n/ razvitie-gibkosti-na-etape-nachalnogo-obucheniya-v-hudozhestvennoy-gimnastike. (in Russ.).

11. Evila-Carvalho L., Klentrou P., Palomero M. d. L., Lebre E. (2014), «Body composition profile of elite group rhythmic gymnastics», Science of Gymnastics Journal, Vol. 4, No. 1, pp. 21-32. (in Eng.).

12. Carvalho L. A., Klentrou P., Lebre E. (2012), «Handling, throws, catches and collaborations in elite group rhythmic gymnastics», Science of Gymnastics Journal, Vol. 4, No. 3, pp. 37-47. (in Eng.).

13. Fortios M., Miltiadis P., Eirini A., Andromahi S. (2012), «Dynamic Balance in Girls Practicing Recreational Rhythmic Gymnastics and Greek Traditional Dances», Science of Gymnastics Journal, Vol. 5, No. 1, pp. 61-70. (in Eng.).

14. Gallahue D. L., Ozmun J. C. (2006), Understanding Motor Development (Infants, Children, Adolescents, and Adults). New York: McGraw-Hill, 125 p. (in Eng.).

15. Kosmidau E., Giannitspoulou E., Proios M. (2015), «Perceived locus of control in rhythmic gymnastics by coaches and judges», Sport Science Review, Vol. XXIV, No. 1-2, pp. 89-102. (in Eng.).

16. Wang Z. (2016), «Proprioception influence on rhythmic gymnastics sport skill formation based on physiology theory», Journal of Chemical and Pharmaceutical Research, Vol. 1, pp. 57-61. (in Eng.).

Received: 04.08.2021.

Published: 31.08.2021

\section{Відомості про авторів / Information about the Authors}

Сомова Катерина Володимирівна: к.мед.наук; Харківська державна академія фізичної культури: вул. Клочківська 99, Харків, 61058, Україна.

Сомова Екатерина Владимировна: к.мед. наук; Харьковская государственная академия физической культуры: ул. Клочковская 99, г. Харьков, 61058, Украина.

Katerina Somova: PhD (Medicine); Kharkiv State Academy of Physical Culture: Klochkovskaya str. 99, Kharkiv, 61058, Ukraine.

ORCID: http://orcid.org/0000-0002-7174-2373

E-mail: kvsomova@gmail.com

Ємець Тетяна Сергіївна: Харківська державна академія фізичної культури: вул. Клочківська 99, Харків, 61058, Україна.

Емец Татьяна Сергеевна: Харьковская государственная академия физической культуры: ул. Клочковская 99, г. Харьков, 61058, Украина.

Tetiana Yemets: Kharkiv State Academy of Physical Culture: Klochkovskaya str. 99, Kharkiv, 61058, Ukraine.

ORCID: http://orcid.org/0000-0002-7796-2318

E-mail: tany59034@gmail.com

Калмикова Юлія Сергіївна: к. фіз.вих., доцент; Харківська державна академія фізичної культури: вул. Клочківська 99, Харків, 61058, Україна.

Калмыкова Юлия Сергеевна: к.физ.восп., доцент; Харьковская государственная академия физической культуры: ул. Клочковская 99, г. Харьков, 61058, Украина.

Yuliya Kalmykova: PhD (Physical Therapy), Associate Professor; Kharkiv State Academy of Physical Culture: Klochkovskaya str. 99, Kharkiv, 61058, Ukraine.

ORCID: http://orcid.org/0000-0002-6227-8046

E-mail: yamamaha13@gmail.com

Калмиков Сергій Андрійович: к.мед.н., доцент; Харківська державна академія фізичної культури: вул. Клочківська 99, Харків, 61058, Україна.

Калмыков Сергей Андреевич: к.мед.н., доцент; Харьковская государственная академия физической культуры: ул. Клочковская 99, г. Харьков, 61058, Украина.

Serhii Kalmykov: PhD (Medicine), Associate Professor; Kharkiv State Academy of Physical Culture: Klochkovskaya str. 99, Kharkiv, 61058, Ukraine.

ORCID: http://orcid.org/0000-0002-6837-2826

E-mail: srgkalmykov@gmail.com 